\title{
25. MINERALOGY AND CHEMISTRY OF HYDROTHERMAL VEINS AND BASALTIC HOST ROCKS AT HOLE 319A AND SITE 321
}

\author{
Robert B. Scott and Steven B. Swanson, Department of Geology, \\ Texas A \& M University, College Station, Texas
}

\section{INTRODUCTION}

Portions of cores from Hole 319A and Site 321 contain vein-filling secondary phases that include sulfides, carbonates, and iron-rich clays and oxides. The host rocks and veins were studied petrographically to identify the mineralogy of the vein-filling material and the nature of the visible alteration of the host rock. In some cases, individual vein-filling minerals were analyzed chemically. Also, whole rock chemical analyses of the host rock were performed to identify the chemical character of the host rock and possible alteration of the host rock adjacent to the veins.

\section{RESULTS}

Two types of veins are present: one forms anastomosing patterns between crystals and has extremely variable thicknesses; the other forms flat sheets of nearly uniform thickness and attitude. The latter may represent cooling joints. Very little alteration is visible in the phenocrysts of the host rocks, but the groundmasses have been extensively altered to smectities, possible zeolites and unidentifiable brownish alteration products. Minute quenched skeletal titanomagnetite, pyroxene, and plagioclase crystals are present in this altered groundmass. The degree of alteration of groundmass and phenocrysts does not visibly increase toward veins. Individual sample descriptions follow at the end of this report.

Table 1 records the oxide weight percentages of major elements, some minor elements, and the elemental abundances of selected trace elements in parts per million of the host rocks. All vestiges of vein-filling material were carefully removed before analysis. The altered chemistry of these basalts falls into a transitional field between tholeiitic and alkalic basalts (Figure 1). The degree of alteration is made apparent by comparison with fresh basalts reported by Hart (1974); the K contents of these altered rocks are several factors higher than those of fresh materials. The averages of the $\mathrm{K}_{2} \mathrm{O}$ wt \% of altered basalts are 0.26 at Hole $319 \mathrm{~A}$ and 0.18 at Site 321, whereas Hart (1974) reports 0.046 at Hole 319A and 0.084 at Site 320 from fresh samples. Because silica is lost during rock-seawater reactions, the original rocks may have been a low-potassium tholeiites.

Water contents measured by S.R. Hart in a survey of basalts from Holes 319A and 321 (revised values) are significantly lower than the values reported here for rocks immediately adjacent to the veins (Hart, 319A average $=1.05$, this study, 319A average $=1.38 ;$ Hart, 321 average $=1.21$, study, 321 average $=2.09$ ). Although the water values are not very high, they are appreciably higher than the approximately $0.5 \mathrm{wt} \%$ or less $\mathrm{H}_{2} \mathrm{O}$ found in freshly quenced oceanic basalts. Hajash (1974) and Mottl et al., (1974) have shown that during high temperature $\left(>200^{\circ} \mathrm{C}\right)$ seawater-basalt interactions, $\mathrm{K}_{2} \mathrm{O}$ is added to glass. In contrast, studies of basalts affected by low-temperature alteration show an increase of $\mathrm{K}_{2} \mathrm{O}$ with increasing degree of alteration and hydration (Thompson, 1973). A negative correlation between $\mathrm{K}_{2} \mathrm{O}$ and $\mathrm{H}_{2} \mathrm{O}$ exists in Hole $319 \mathrm{~A}$ and Site 321 rocks adjacent to veins. This suggests that these rocks may have undergone a pervasive influx of $\mathrm{K}$ during lowtemperature alteration, followed by localized removal of $\mathrm{K}$ by hydrothermal fluids in excess of $200^{\circ} \mathrm{C}$.

Within the veins, a conspicuous bluish-green to light emerald-green clay mineral is commonly found coating veins. Because of sampling difficulties, a powder camera $\mathrm{X}$-ray technique was used to determine the mineralogy (Table 2). Also, because of the similarity of the X-ray data to those of nontronite and the nickel-rich serpentine, garnierite, partial chemical analyses were made on microsamples of both the light emerald-green and the bluish-green specimen (Table 3). The low Ni contents (400-500 ppm), low $\mathrm{Al}_{2} \mathrm{O}_{3}$ contents (2.1\%), and high $\mathrm{Fe}_{2} \mathrm{O}_{3}$ contents $(20 \%)$ confirm that these minerals are probably nontronitic smectites. Lesser quantities of similar clays are found in the groundmasses of the host rocks.

Calcium carbonate occurs as veins and as amygdule filling; calcite was found in these samples although aragonite was reported in some in Sample 319A-2-1, $143-146 \mathrm{~cm}$. Sample 321-14-1, 120-212 cm has 2\% drusy calcite and smectite fillings; this sample has the lowest oxide total and the highest $\mathrm{CaO}$ content of the Site 321 samples, probably due to the carbonate.

Petrographic study indicates that pyrite is the most common sulfide; Sample 321-14-2, 135-138 cm contains minute crystals of chalcopyrite intergrown with pyrite in the veins. Minor amounts of marcasite and chalcopyrite were identified by X-ray diffraction (Table 4). No other sulfides were observed. Table 5 summarizes the electronbeam microanalyzer study of the pyrite, determined with the ARL probe at the University of Texas at Dallas and the aid of James Carter. With the exception of the less than $0.15 \% \mathrm{Cu}$, the pyrite is nearly pure $\mathrm{FeS}_{2}$; this pyrite has an order of magnitude less $\mathrm{Cu}$ than found in stratiform cupreous pyrite bodies in ophiolites (Hutchinson, 1974).

The sulfur content of the country rock is much lower than the sulfur solubility limits determined by Haughton et al. (1974). Their study indicates that the solubility of sulfur is directly related to the $\mathrm{FeO}$ content in magmas. From studies of the quenched glasses on pillow margins, the original sulfur contents of median-valley tholeiites are found to be close to the saturation values expected 
TABLE 1

Results From Chemical Analyses of Basalt Samples, Hole 319A and Site 321

\begin{tabular}{|c|c|c|c|c|c|c|c|c|c|c|c|c|}
\hline $\begin{array}{c}\text { Sample } \\
\text { (Interval in } \mathrm{cm} \text { ) }\end{array}$ & $\begin{array}{c}\mathrm{SiO}_{2} \\
(\%)\end{array}$ & $\underset{(\%)}{\mathrm{Al}_{2} \mathrm{O}_{3}}$ & $\begin{array}{c}\mathrm{FeO}^{\mathrm{a}} \\
(\%)\end{array}$ & $\begin{array}{l}\mathrm{MnO} \\
(\%)\end{array}$ & $\underset{(\%)}{\mathrm{MgO}}$ & $\begin{array}{r}\mathrm{CaO} \\
(\%)\end{array}$ & $\begin{array}{c}\mathrm{Na}_{2} \mathrm{O} \\
(\%)\end{array}$ & $\begin{array}{c}\mathrm{K}_{2} \mathrm{O} \\
(\%)\end{array}$ & $\underset{(\%)}{\mathrm{H}_{2} \mathrm{O}^{\mathrm{b}}}$ & $\begin{array}{c}\mathrm{S}^{\mathrm{c}} \\
(\mathrm{ppm})\end{array}$ & $\begin{array}{c}\mathrm{Ni} \\
(\mathrm{ppm})\end{array}$ & $\begin{array}{c}\mathrm{Cu} \\
(\mathrm{ppm})\end{array}$ \\
\hline \multicolumn{13}{|l|}{ Hole 319A } \\
\hline $2-1,144-150$ & 49.3 & 14.6 & 12.2 & 0.18 & 6.88 & 12.3 & 3.06 & 0.210 & 1.15 & 170 & 200 & 77 \\
\hline $2-2,129-133$ & 49.0 & 14.0 & 13.9 & 0.26 & 6.57 & 10.9 & 2.81 & 0.297 & 1.34 & 10 & 200 & 67 \\
\hline $3-2,22-23$ & 49.7 & 14.6 & 12.3 & 0.17 & 6.49 & 11.4 & 2.86 & 0.131 & 1.48 & 1900 & 220 & 74 \\
\hline $3-2,81-87$ & 47.9 & 14.6 & 13.4 & 0.24 & 5.59 & 12.1 & 2.85 & 0.331 & 1.06 & 60 & 230 & 73 \\
\hline $3-5,42-49$ & 49.2 & 14.1 & 13.3 & 0.20 & 6.73 & 11.1 & 2.82 & 0.323 & 1.87 & 40 & 200 & 71 \\
\hline \multicolumn{13}{|l|}{ Site 321} \\
\hline \multirow{4}{*}{$\begin{array}{l}14-1,120-121 \\
14-2,135-138 \\
14-3,101-100 \\
\text { Precision, \% of } \\
\text { value measured }\end{array}$} & 49.0 & 13.6 & 13.9 & 0.26 & 5.97 & 10.7 & 2.46 & 0.315 & 1.06 & 2080 & 220 & 73 \\
\hline & 49.1 & 13.6 & 14.5 & 0.19 & 6.75 & 9.2 & 2.64 & 0.140 & 2.20 & 260 & 220 & 67 \\
\hline & 48.6 & 13.6 & 14.2 & 0.17 & 7.97 & 8.5 & 2.50 & 0.096 & 3.01 & 650 & 220 & 59 \\
\hline & \pm 1.0 & \pm 2.0 & \pm 2.5 & \pm 2.0 & \pm 0.5 & \pm 3.0 & \pm 1.0 & \pm 1.0 & \pm 5.0 & \pm 2.0 & \pm 10 & \pm 2.0 \\
\hline
\end{tabular}

Note: Atomic absorption spectrophotometric methods (Perkin-Elmer 306) were used to measure the $\mathrm{Al}, \mathrm{Fe}, \mathrm{Mn}, \mathrm{Mg}, \mathrm{Ca}$, $\mathrm{Na}, \mathrm{K}, \mathrm{Ni}$, and $\mathrm{Cu}$ abundances. Si was determined by the ammonium molybdate colorimetric method with a Beckman DBGT spectrophotometer. Total water was determined by a modified Penfield method. Sulfur determinations were made by automatic titration of a $\mathrm{KIO}_{3}$-starch solution with a dilute $\mathrm{HC} 1$ solution; $\mathrm{SO}_{2}$ gas was extracted by passing oxygen through the sample in an induction furnace.

a Total iron expressed as $\mathrm{FeO}$.

b Total water.

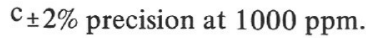

TABLE 2

Results From X-Ray Diffraction Studies of the Bluish-Green and Light Green Clay Mineral

\begin{tabular}{lc}
\hline $\begin{array}{l}\text { Fe-Rich Clay } \\
d \text {-Spacing A }\end{array}$ & $\begin{array}{c}\text { Nontronite } \\
d \text {-Spacing A }\end{array}$ \\
\hline $15_{\mathrm{EB}}[100]$ & $15.4[100]$ \\
$4.58[70]$ & $4.56[100]$ \\
3.21 & 3.11 \\
& 2.64 \\
$2.65-2.40 \mathrm{VB}$ & 2.56 \\
& 2.43 \\
1.74 & 1.72 \\
& 1.67 \\
$1.53[80]$ & $1.52[100]$ \\
$1.32 \mathrm{~B}$ & 1.32 \\
& 1.30 \\
\hline
\end{tabular}

NOTE: EB = Extremely broad, approximate only; VB $=$ Very broad; $\mathrm{B}=$ Broad.

${ }^{\mathrm{a}} \mathrm{Cu}-\mathrm{K} \alpha$ radiation, Ni filter.

${ }^{\mathrm{b}} \mathrm{X}$-ray analysis of nontronite as reported by Nagelschmidt (1938).

from the FeO contents (Scott and Frank, 1974), but holocrystalline diabases, gabbros, and their metamorphosed extrusive and intrusive equivalents are below saturation values. Hole 319A rocks have lost an average of $530 \mathrm{ppm}$ sulfur and Site 321 rocks have lost an average of $200 \mathrm{ppm}$ based upon their $\mathrm{FeO}$ contents and the assumption that they were originally saturated with sulfur. Two rocks, 34-319A-3, 22-33 cm and 34$321-14,120-121 \mathrm{~cm}$ both have sulfur far in excess of its expected solubility; primary sulfide crystals are disseminated within these host rocks and it is possible that magmatic segregation may have locally concentrated them. Thus, the source of the pyrite in the veins is open to question; the sulfur may have come from the host rock itself, from some other rock now depleted in sulfur, or from the reduction of seawater sulfate; at present, the possiblity of a seawater source is being investigated using isotopic techniques. C.W. Field (this volume) finds a spread in $\delta^{34} \mathrm{~S}$ valves from secondary sulfides recovered from Leg 34 basalts that is too great to distinguish among sulfurs from a bacteriological reduction of seawater sulfate, an inorganic reduction by reaction between seawater sulfate and rock, or a remobilization of magmatic sulfur. An unambiguous answer to the question of the role and origin of sulfur in hydrothermal systems in the ocean crust is critical to oceanic mass balance calculations besides potential economic interest in the ocean crust.

The opaque iron-titanium oxides show a distinct change in mineralogy close to the secondary veins; deep within the host rock, equant titanomagnetites are abundant, but closer to veins, an opaque, needle-shaped mineral is commonly aligned subperpendicular to the veins, forming an obvious secondary texture. The results of semiquantitiative microprobe analyses confirms that this mineral is probably titaniferous maghemite. Iron oxides (hematite?) and minor amounts of manganese (?) oxides are commonly found coating walls of veins filled with calcite.

The temperature of the hydrothermal solutions that affected the rocks cannot be determined by the phases 


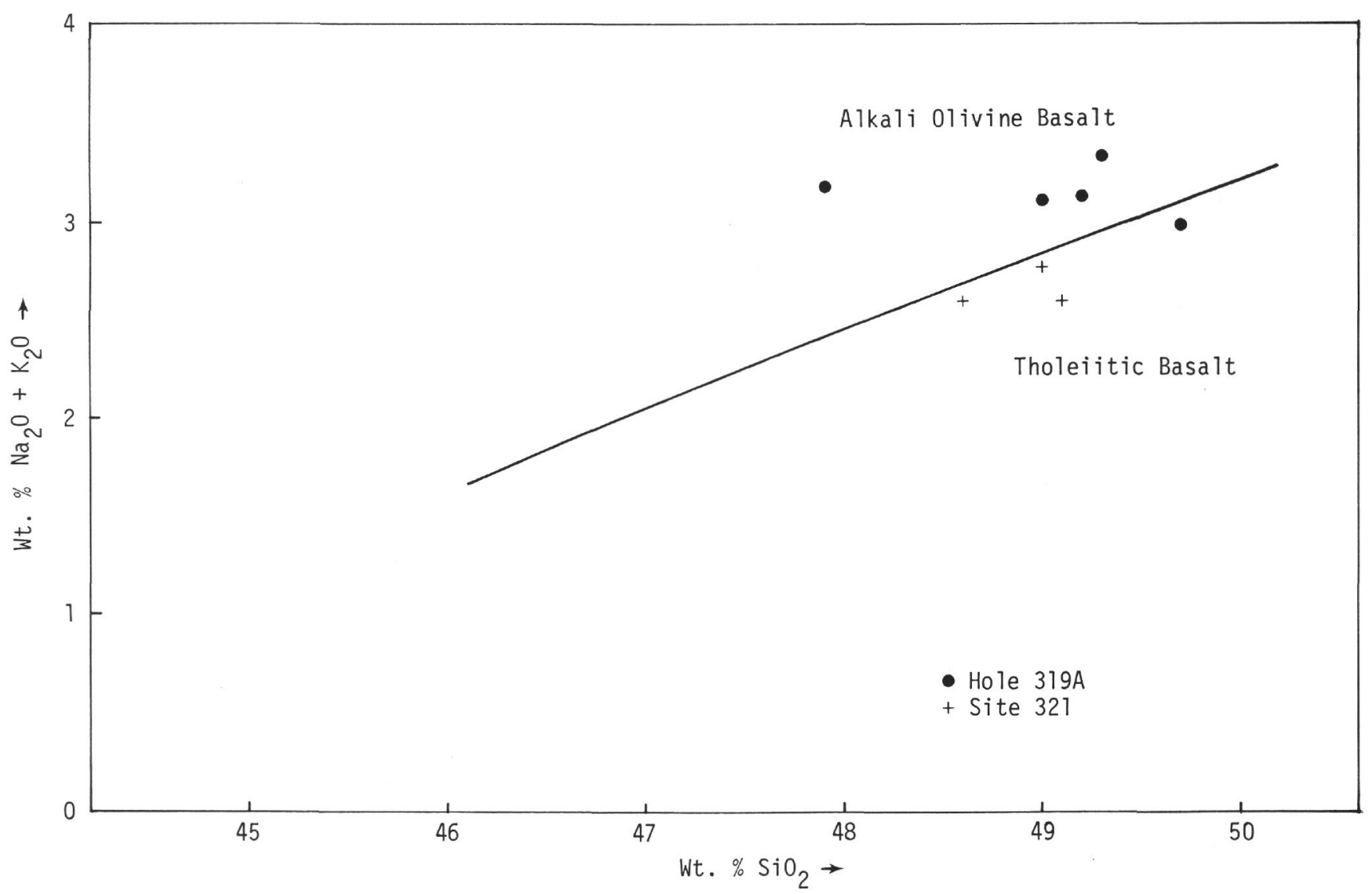

Figure 1. Total alkali-silica diagram of altered basalt samples, Hole 319A and Site 321.

TABLE 3

Results From Chemical Analyses of the Bluish-Green and Light Green Smectites

\begin{tabular}{ccccccccc}
\hline $\begin{array}{c}\text { Sample } \\
(\text { Interval in cm) }\end{array}$ & $\begin{array}{c}\text { Sample } \\
\text { wt (g) }\end{array}$ & $\begin{array}{c}\mathrm{Al}_{2} \mathrm{O}_{3} \\
(\%)\end{array}$ & $\begin{array}{c}\mathrm{Fe}_{2} \mathrm{O}_{3}{ }^{\mathrm{a}} \\
(\%)\end{array}$ & $\begin{array}{c}\mathrm{MnO} \\
(\%)\end{array}$ & $\begin{array}{c}\mathrm{MgO} \\
(\%)\end{array}$ & $\begin{array}{c}\mathrm{Ni} \\
(\mathrm{ppm})\end{array}$ & $\begin{array}{c}\mathrm{Co} \\
(\mathrm{ppm})\end{array}$ & $\begin{array}{c}\mathrm{Cu} \\
(\mathrm{ppm})\end{array}$ \\
\hline $\begin{array}{c}\text { Blue-green smectite } \\
\text { 321-14-1, 120-121 }\end{array}$ & 0.007 & n.d. & 20.2 & 0.04 & 8.5 & 500 & 300 & 100 \\
$\begin{array}{c}\text { Light green smectite } \\
\text { 319A-2-1, 144-150 }\end{array}$ & 0.006 & 2.1 & 20.0 & 0.025 & 8.2 & 400 & 300 & 300 \\
\hline
\end{tabular}

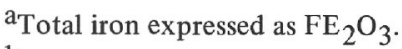

$\mathrm{b}_{\mathrm{n} . \mathrm{d} .}=$ not determined.

TABLE 4

Results From X-Ray Diffraction Studies of Sulfides in Sample 321-14-2, 135-138 cm

\begin{tabular}{llllll}
\hline \multicolumn{2}{c}{ Chalcopyrite } & \multicolumn{2}{c}{ Marcasite } & \multicolumn{2}{c}{ Pyrite } \\
\multicolumn{2}{c}{$\begin{array}{l}\text {-Spacing } \\
\mathrm{A}\end{array}$} & $\mathrm{I} / \mathrm{I}$ & $\mathrm{A}$ & $\mathrm{I}$-Spacing & \multicolumn{2}{c}{$d$-Spacing } \\
& & $\mathrm{A}$ & $\mathrm{A}$ & $\mathrm{I} / \mathrm{I}$ \\
\hline 3.03 & \multirow{2}{*}{$(100)$} & 2.71 & $(100)$ & 1.63 & $(100)$ \\
& & 1.76 & $(63)$ & 2.70 & $(84)$ \\
& & & 2.42 & $(66)$ \\
\hline
\end{tabular}

Note: All reflections observed for chalcopyrite and marcasite are reported. Only the three strongest pyrite reflections are reported.

that fill the veins. The anastomosing veins contain pyrite, minor amounts of chalcopyrite, traces of marcasite, and a nontronitic smectite. Hajash (1974; per- sonal communication) has grown chalcopyrite, pyrrhotite, marcasite, and an emerald-green smectite by reactting tholeiitic oceanic basalt with seawater at $500^{\circ} \mathrm{C}$ and $0.6 \mathrm{~kb}$. The marcasite may be metastable at high temperatures. The presence of a trace of marcasite in the veins of Leg 34 basalts may suggest a lower temperature origin or acid conditions, or metastability (Stanton, 1972 , p. 81-82; Palache, et al., 1944, p. 313). The stabilities of pyrite, chalcopyrite, and even pyrrhotite cover a range from at least $600^{\circ} \mathrm{C}$ to $25^{\circ} \mathrm{C}$ (Stanton, 1972, fig. 5-20). In any case, the anastomosing veins of sulfides and smectite probably formed under conditions of relatively low oxygen fugacity and high sulfur fugacity, whereas the sheet-like veins of oxides, smectites, and carbonates probably formed under relatively high $\mathrm{PCO}_{2}$ and oxygen fugacity conditions. Such variations of chemical conditions between periods of vein formation 
TABLE 5

Results From Electron-Beam Microanalysis Study of Pyrite, Sample 321-14-2, 135-138 cm

\begin{tabular}{lcccccccr}
\hline Pyrite & $\mathrm{S}(\%)$ & $\mathrm{Fe}(\%)$ & $\mathrm{Ni}(\mathrm{ppm})$ & $\mathrm{Cu}(\mathrm{ppm})$ & $\mathrm{As}(\mathrm{ppm})$ & $\mathrm{Sb}^{\mathrm{a}}$ & $\mathrm{Co}^{\mathrm{b}}$ & $\mathrm{Zn}^{\mathrm{c}}$ \\
\hline $321-14-2,135-138$ & 53.45 & 45.31 & 380 & 1,370 & 170 & n.d. & n.d. & d. \\
\hline
\end{tabular}

${ }^{\mathrm{a}} \mathrm{Sb}$ not detected by either energy nondispersive or energy dispersive X-ray unit.

${ }^{b}$ Co not detected by energy dispersive X-ray unit.

$\mathrm{c}_{\mathrm{Zn}}$ detected by energy dispersive $\mathrm{X}$-ray unit.

suggests that these rocks were subjected to a complex hydrothermal history. Bass (1974) considers a few chlorite-rich veins to be deuteric; we consider that anastomosing sulfide veins were probably formed at relatively high temperatures $\left(>200^{\circ} \mathrm{C}\right)$. Obviously definitive research on the genesis of veins is necessary for an understanding of the chemical evolution of oceanic igneous rocks.

\section{ROCK DESCRIPTIONS}

319A-2-1, 143-146 cm: Basalt with a 1-mm-wide uniform vein, with the following sequence across the vein: rock-iron oxide-aragonite-smectite-iron oxide-rock. About $16 \%$ of the rock consists of fine-grained greenishbrown alteration products in the groundmass.

319A-2-1, 144-150 cm: Basalt with a 0.1-mm-wide anastomosing vein of pyrite and blue-green to emeraldgreen smectite. About $12 \%$ of the rock consist of brownish alteration products in the groundmass.

319A-2-2, 129-133 cm: Basalt with a 0.1-mm-wide anastomosing vein of iron oxides and calcite. About $10 \%$ of the rock consists of yellowish-brown alteration products in the groundmass.

319A-3-2, 22-23 cm: Basalt with a 0.1-mm-wide anastomosing vein of pyrite and blue-green to emeraldgreen smectite and a $0.1-\mathrm{mm}$-wide vein of pyrite. About $10 \%$ of the rock consists of isotropic brownish alteration products in the groundmass. A small amount of primary pyrite is disseminated in the rock.

319A-3-2, 81-87 cm: Basalt with two 1-mm-wide uniform calcite veins. About $7 \%$ of the rock consists of reddish-brown alteration products with hematitic optical character, and about $9 \%$ of the rock consists of yellowish smectite; both alteration products are in the groundmass.

319A-3-2, 42-29 cm: Basalt with a 2-mm-wide uniform vein of calcite and reddish-brown iron oxides with the following sequence across the vein: rock; discontinuous layers of iron oxides with some manganiferous portions; reddish-brown calcite; discontinuous layers of iron oxides with some manganiferous portions; rock. About $20 \%$ of the rock consists of yellowish-brown alteration products in the groundmass.
321-14-1, 120-121 cm: Vesicular basalt with 0.1-mmwide anastomosing vein of pyrite and blue-green to emerald-green smectite. Vesicles are filled with calcite and smectite. Vesicles form $2 \%$ of the rock. About $17 \%$ of the rock consists of grayish-brown alteration products in the groundmass. A small amount of disseminated primary pyrite is in the rock.

321-14-2, 135-138 cm: Vesicular basalt with $0.1-\mathrm{mm}$ wide anastomosing vein of pyrite and gray smectite. A few chalcopyrite crystals are scattered within the pyrite. About $15 \%$ of the rock consists of grayish-brown alteration products in the groundmass.

321-14-3, 101-110 cm: Basalt with 0.1-mm-wide anastomosing veins of greenish smectite.

\section{REFERENCES}

Bass, M.N., 1974. Secondary minerals in basalt, DSDP Leg 34: Geol. Soc. Am. Abstracts, v. 6, p. 646.

Hajash, A., 1974. An experimental investigation of high temperature seawater-basalt interations: Geol. Soc. Am. Abstracts with Programs, v. 6, p. 771.

Hart, S.R., 1974. IL-element geochemistry, Leg 34 basalts: Geol. Soc. Am. Abstracts with Programs, v. 6, p. 780-781.

Haughton, D.R., Roeder, P.L., and Skinner, B.J., 1974. Solubility of sulfur in mafic magmas: Econ. Geol., v. 69, p. $451-467$.

Hutchinson, R.W., 1974. Volcanogenic sulfide deposits and their metallogenic significance: Econ. Geol., v. 68, p. 12231246.

Mottl, M.J., Corr, R.F., and Holland, H.D., 1974. Chemical exchange between seawater and mid-ocean ridge basalt during hydrothermal alteration: an experimental study: Geol. Soc. Am. Abstracts with Programs, v. 6, p. 879-880.

Nagelschmidt, G., 1938. On the atomic arrangement and variability of the members of the montmorillonite group: Min. Mag., v. 25, p. 140-155.

Palache, C., Berman, H., and Frondel, C., 1944. Dana's system of mineralogy: 7th ed., v. I, New York (John Wiley and Sons).

Scott, R.B. and Frank, J.D., 1974. Distribution of sulfur in the ocean crust: Geol. Soc. Am. Abstracts with Programs, v. 6, p. 945 .

Stanton, R.L., 1972. Ore petrology: New York (McGrawHill).

Thompson, G., 1973. A geochemical study of the lowtemperature interaction of seawater and oceanic igneous rocks: Am. Geophys. Union Trans., v. 54, p. 1015-1019. 